Bangladesh J. Plant Taxon. 28(1): 271-276, 2021 (June)

(C) 2021 Bangladesh Association of Plant Taxonomists

https://doi.org/10.3329/bjpt.v28i1.54222

- Short communication

\title{
ANGIOSPERMIC FLORA OF WADI AL AQIQ IN AL-MADINAH AL- MUNAWARAH, SAUDI ARABIA
}

\author{
Wael A. Obaid and Usama K. Abdel-Hameed ${ }^{1} *$ \\ Department of Biology, College of Science, Taibah University, Kingdom of Saudi Arabia
}

Keywords: Chorology; Plant habit; Life forms.

Floristic investigations are not only essential to know the diversity of plants present in any area, but also are significant socio-economically. Floristic elements may provide food and medicine for human beings and other animal species of the area of occurrence (Shehata and Galal, 2015). Surveys on biodiversity, including the floras, are important for determining the phytodistribution data required for analyses and for modeling the plants responses to global climatic changes (Llewellyn et al., 2010). As floristic analyses are prerequisite for plant species conservation, it is critical to examine the current status of floristic and species diversity to provide appropriate guidelines for developing effective system of conservation and management.

Kingdom of Saudi Arabia with the coordinates of $32^{\circ} 34^{`} \mathrm{~N}-16^{\circ} 83^{`} \mathrm{~N}, 34^{\circ} 36^{\circ} \mathrm{E}-56^{\circ} \mathrm{E}$ contains large arid desert that has an approximate area of 2, 250,000 $\mathrm{km}^{2}$ and covers the main portion of the Arabian Peninsula, where the xerophytes contributes the most plant life form (Zahran, 1982). Due to its vast area, the Kingdom of Saudi Arabia contains different habitats including salt pans, valleys, mountains, rocky and sandy deserts (Alsherif et al., 2013). Wadis (viz. Wadi Al Aqiq) resemble physiographic variabilities that lead to great variation in plants distribution (Kassas and Girgis, 1964). The flora of Saudi Arabia was comprehensively studied (Chaudhary, 1999 and 2001; Collenette, 1999), but only few studies on the local or regional floras of limited portions of the country including Asir region (Hosni et al., 1996), Al-Qassim region (Al-Turki, 1997) and Hail region (Al-Turki and Al-Olayan, 2003; El-Ghanim et al., 2010) were conducted. Thus the specific floristic inventories in the local areas of Saudi Arabia are not yet sufficient. Despite the previous studies on the flora of Saudi Arabia, there are no extensive surveys on the plant diversity, life forms and chorology of plants in Al Madinah region.

Al Madinah region including Wadi Al Aqiq (upstream, midstream and downstream), located between $24^{\circ} 34^{\prime} 34^{\prime \prime} \mathrm{N}$ and $39^{\circ} 34^{\prime} 58^{\prime \prime} \mathrm{E}$, has an area of $151,990 \mathrm{~km}^{2}$, mostly coated by bare soil (96\%). The region of the current investigation is located in the west of Saudi Arabia that lies within the Nubo-Sindian Province (Zohary, 1973) or Nubo-Sindian local centre of endemism- a subzone of the Saharo-Sindian region. This zone was typified by a xero-tropical vegetation of desert habitats requiring high temperatures and low rainfall and was considered to be of palaeotropical origin (Llewellyn et al., 2010; White and Léonard, 1991). Its UTM position is EH51 and Joint Operation Graphics reference is NG37-15 (Fig. 1). Al Madinah contains little variations in elevation. The average elevation is $610.51 \mathrm{~m}$ above sea level, while the most remarkable variations in elevation $(2019.91 \mathrm{~m})$ are found through fifty miles. Wadi Al Aqiq is considered as one of the biggest basins in Kingdom of Saudi Arabia.

Geologically, it is an important section of the middle-western Precambrian Arabian Shield (El Maghraby, 2014). In the study area, winter is short, comfortable, dry and windy, while summer is

*Corresponding author. E-mail: usama_abdelhameed@sci.asu.edu.eg

${ }^{1}$ Department of Botany, Faculty of Science, Ain Shams University, Egypt. 
long, arid and sweltering. In general, temperature is rarely above $114^{\circ} \mathrm{F}$ or below $47^{\circ} \mathrm{F}$. The hot season lasts for 4.6 months (during May to October), while the cool season lasts for 2.9 months (during November to February). The sliding days of rainfall and the perceived humidity level in Al-Madinah stay around 0.1 inches and $1 \%$ respectively and does not vary significantly over the year.

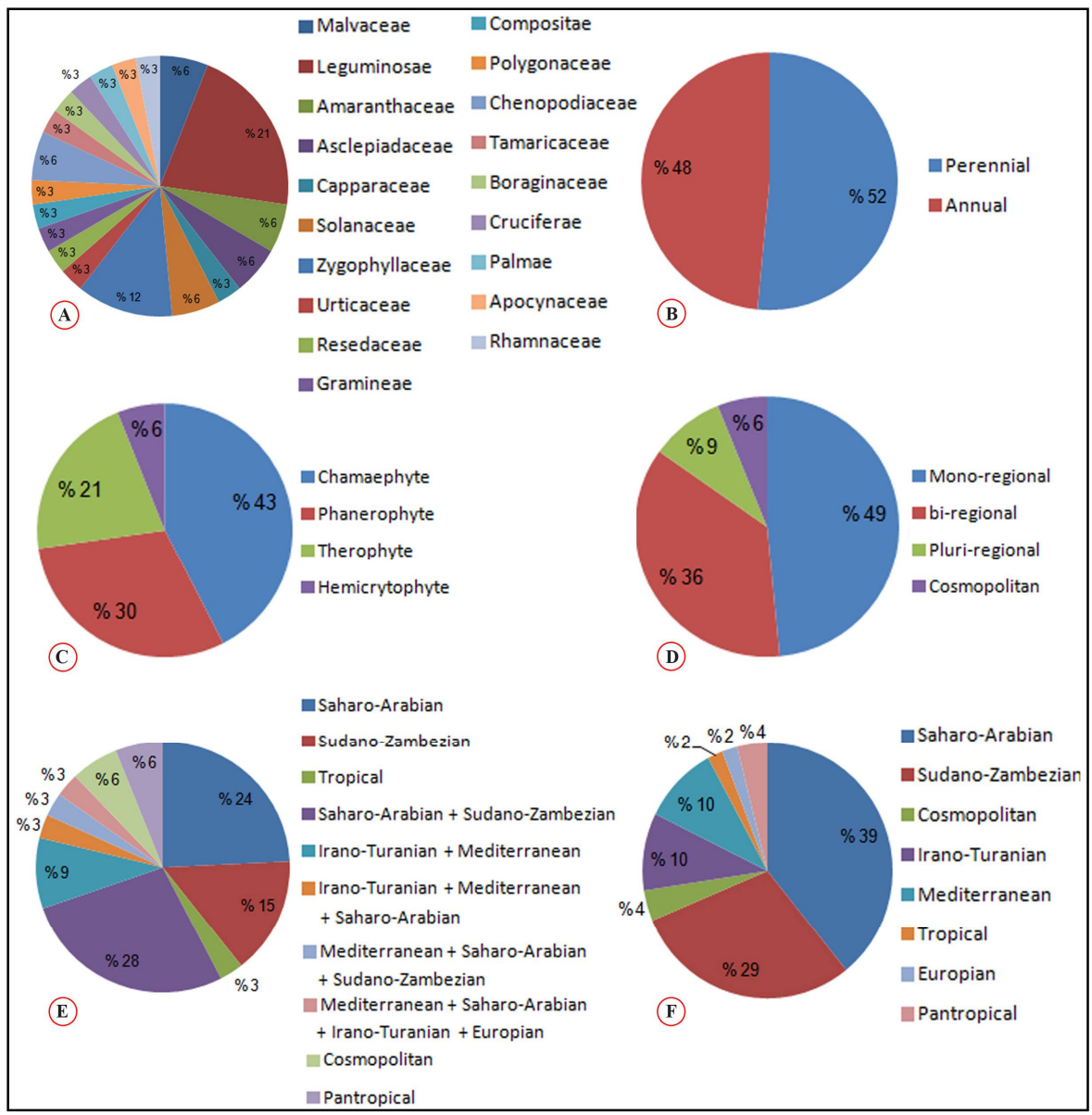

Fig. 1. A. Percentage of the represented families, B. Frequency of plant habit, C. Life form relative spectrum, D., E., and F. Floristic category spectrum of the recorded plants in $\mathrm{Al}$ Madinah region.

This study was performed to collect the base-line data on the angiospermic flora of Wadi Al Aqiq, Al Madinah Al Munawarah, Kingdom of Saudi Arabia. Such data would be useful in the assessment of plant diversity, plant life forms and chorology of the flora and in developing an effective system of conservation and management to help in the ecological restoration of some populated localities within the valley.

In this study, the meteorological data were gathered from weatherspark.com and https://www.yr.no/depending on two weather stations: Yanbu Airport (67\%, 84 kilometers, northwest) and Prince Mohammad bin Abdul Aziz Airport (33\%, 126 kilometers, northeast). The identification and authentication of the collected plant taxa (Table 1) were performed depending 
on (Chaudhary, 2001; Collenette, 1999; Migahid, 1996). Voucher specimens were kept in the publicly herbarium of the Department of Biology at Taibah University. Life forms were detected according to (Raunkiaer, 1934), while the chorotypes were determined according to (Zohary, 1973).

Table 1. Plant species and family name that were collected from Wadi Al Aqiq, Saudi Arabia.

\begin{tabular}{|c|c|c|}
\hline No. & Plant species & Family name \\
\hline 1. & Abutilon fruticosum Guill. \& Perr., Fl. Seneg. Tent. 1: 70.1831 (GCI) & Malvaceae \\
\hline 2. & Acacia ehrenbergiana Hayne, Getreue Darstell. Gew. x. t. 29. (IK) & Leguminosae \\
\hline 3. & Acacia tortilis Hayne, Getreue Darstell. Gew. ix. I. 31. (IK) & Leguminosae \\
\hline 4. & Aerva javanica Juss., Ann. Mus. Natl. Hist. Nat. 2: 131. 1803 (IK) & Amaranthaceae \\
\hline 5 . & Amaranthus viridis L., Species Plantarum ed. 21763 (APNI) & Amaranthaceae \\
\hline 6. & Calotropis procera W.T.Aiton, Hort. Kew., ed. 2 [W.T. Aiton] 2: 78. 1811 (IK) & Asclepiadaceae \\
\hline 7. & Capparis spinosa L., Sp. Pl. 1: 503. 1753 [1 May 1753] (IK) & Capparaceae \\
\hline 8 . & Cassia italica Lam. ex F.W.Andrews, Fl. Pl. Anglo-Egypt. Sudan ii. 117 (1952). (IK) & Leguminosae \\
\hline 9. & Datura innoxia Mill., Gard. Dict., ed. 8. Datura no. 5. 1768 [16 Apr 1768] (GCI) & Solanaceae \\
\hline 10. & Fagonia schweinfurthii (Hadidi) M.Hall, Edinburgh J. Bot. 68(2): 197. 2011 & Zygophyllaceae \\
\hline 11. & Forsskaolea tenacissima L., Opobalsamum 18. 1764 [22 Dec 1764] (IK) & Urticaceae \\
\hline 12. & Leucaena leucocephala (Lam.) de Wit, Taxon x. 54 (1961). (IK) & Leguminosae \\
\hline 13. & Malva parviflora Huds., Fl. Angl. (Hudson) 268. 1762 (IK) & Malvaceae \\
\hline & Ochradenus baccatus Delile, Descr. Egypte, Hist. Nat. 236, t. 31. (IK) & Resedaceae \\
\hline 15 . & Parkinsonia aculeata L., Species Plantarum 21753 (APNI) & Leguminosae \\
\hline & Phoenix dactylifera L., Species Plantarum 21753 (APNI) & Palmae/(Arecaceae) \\
\hline & Phragmites australis (Cav.) Steud., Nomencl. Bot. ed. 2, 1: 143 (1840):. (IK) & Gramineae \\
\hline & Prosopis juliflora DC., Prodr. [A. P. de Candolle] 2: 447.1825 (IK) & Leguminosae \\
\hline 19. & Pulicaria incisa DC., Prodr. [A. P. de Candolle] 5: 479. 1836 [1-10 Oct 1836] (IK) & Compositae \\
\hline 20. & Rhazya stricta Decne., Ann. Sci. Nat., Bot. sér. 2, 4: 80.1835 (IK) & Apocynaceae \\
\hline 21. & Rumex vesicarius L., Species Plantarum 21753 (APNI) & Polygonaceae \\
\hline & Sesbania sesban Britton, Brooklyn Bot. Gard. Mem. i. 54 (1918). (IK) & Leguminosae \\
\hline 23. & Solanum nigrum L., Species Plantarum 21753 (APNI) & Solanaceae \\
\hline 24. & Solenostemma oleifolium (Nectoux) Bullock \& E.A.Bruce, Kew Bull. 8(3): 359. (IK) & Asclepiadaceae \\
\hline 25 . & Suaeda aegyptiaca (Hasselq.) Zohary, J. Linn. Soc., Bot. lv. 635 (1957). (IK) & Chenopodiaceae \\
\hline 26. & Suaeda monoica Forssk. ex J.F.Gmel., in Onomat. Bot. Compl. 8: 798 (1776). (IK) & Chenopodiaceae \\
\hline 27. & Tamarix aphylla (L.) H.Karst., Deut. Fl. (Karsten) 641. 1882 [May 1882] (IK) & Tamaricaceae \\
\hline 28. & Tribulus macropterus Boiss., Diagn. Pl. Orient. ser. 1, 1: 61.1843 [Jan-Feb 1843] (IK) & Zygophyllaceae \\
\hline 29. & Trichodesma africanum (L.) Lehm., Pl. Fam. Asperif. 195. 1818 (IK) & Boraginaceae \\
\hline & Zilla spinosa Prantl, Nat. Pflanzenfam. [Engler \& Prantl] iii. 2 (1891) 175. (IK) & Cruciferae \\
\hline 31. & Ziziphus spina-christi (L.) Willd., Sp. Pl., ed. 4 [Willdenow] 1(2): 1105. 1798 (IK) & Rhamnaceae \\
\hline & Zygophyllum coccineum L., Sp. Pl. 1: 386. 1753 [1 May 1753] (IK) & Zygophyllaceae \\
\hline 33. & $\begin{array}{l}\text { Zygophyllum simplex } \text { L., Mant. Pl. } 68.1767 \\
=\text { Tetraena simplex }(\text { L.) Beier \& Thulin, Pl. Syst. Evol. 240(1-4): } 36 \text { (2003). }\end{array}$ & Zygophyllaceae \\
\hline
\end{tabular}

This study identified total 33 plant taxa distributed in 31 genera and 19 families (Table 1). Leguminosae and Zygophyllaceae are the largest families in the study area. The major plant families were Leguminosae (Fabaceae, Mimosaceae and Caesalpiniaceae) with seven species, Zygophyllaceae with four species, Malvaceae, Amaranthaceae, Asclepiadaceae, Solanaceae and Chenopodiaceae, each with two species, and the rest of the families (12 families) with one species each. Another seven families were existed with two to seven species each (Table 1, Fig. 1A). Few 
species were found to be modified and survived in tough environments and in contrast, it was inferred that few others could not survive and might have been extinct.

Table 2. Plant species that were investigated from the scanned area and their habitats, life forms and chorotypes.

\begin{tabular}{|c|c|c|c|c|}
\hline No. & Plant species & Habitat & Life form & Chorotype \\
\hline 1. & Abutilon fruticosum & Perennial & Chamaephyte & Saharo-Arabian \\
\hline 2. & Acacia ehrenbergiana & Perennial & Phanerophyte & Sudano-Zambezian \\
\hline 3. & Acacia tortilis & Perennial & Phanerophyte & Sudano-Zambezian \\
\hline 4. & Aerva javanica & Perennial & Chamaephyte & Saharo-Arabian + Sudano-Zambezian \\
\hline 5. & Amaranthus viridis & Annual & Therophyte & Cosmopolitan \\
\hline 6. & Calotropis procera & Perennial & Phanerophyte & Saharo-Arabian + Sudano-Zambezian \\
\hline 7. & Capparis spinosa & Perennial & Chamaephyte & Irano-Turanian + Mediterranean; \\
\hline 8. & Cassia italica & Annual & Chamaephyte & Sudano-Zambezian \\
\hline 9. & Datura innoxia & Annual & Chamaephyte & Saharo-Arabian \\
\hline 10 . & Fagonia schweinfurthii & Annual & Chamaephyte & Saharo-Arabian \\
\hline 11. & Forsskaolea tenacissima & Annual & Chamaephyte & Saharo-Arabian + Sudano-Zambezian \\
\hline 12. & Leucaena leucocephala & Perennial & Phanerophyte & Pantropical \\
\hline 13. & Malva parviflora & Annual & Therophyte & Mediterranean + Irano-Turanian \\
\hline 14. & Ochradenus baccatus & Perennial & Chamaephyte & Saharo-Arabian + Sudano-Zambezian \\
\hline 15. & Parkinsonia aculeata & Perennial & Phanerophyte & Pantropical \\
\hline 16. & Phoenix dactylifera & Perennial & Phanerophyte & Saharo-Arabian + Sudano-Zambezian \\
\hline 17. & Phragmites australis & Perennial & Hemicrytophyte & $\begin{array}{l}\text { Irano-Turanian + Mediterranean + Saharo- } \\
\text { Arabian }\end{array}$ \\
\hline 18. & Prosopis juliflora & Perennial & Phanerophyte & Saharo-Arabian \\
\hline 19. & Pulicaria incisa & Annual & Therophyte & Saharo-Arabian + Sudano-Zambezian \\
\hline 20. & Rhazya stricta & Perennial & Chamaephyte & Saharo-Arabian + Sudano-Zambezian \\
\hline 21. & Rumex vesicarius & Annual & Therophyte & $\begin{array}{l}\text { Mediterranean + Saharo-Arabian + Sudano- } \\
\text { Zambezian }\end{array}$ \\
\hline 22. & Sesbania sesban & Perennial & Phanerophyte & Tropical \\
\hline 23. & Solanum nigrum & Annual & Therophyte & Cosmopolitan \\
\hline 24. & Solenostemma oleifolium & Annual & Chamaephyte & Saharo-Arabian \\
\hline 25 . & Suaeda aegyptiaca & Annual & Hemicrytophyte & Saharo-Arabian \\
\hline 26. & Suaeda monoica & Annual & Chamaephyte & Sudano-Zambezian \\
\hline 27. & Tamarix aphylla & Perennial & Phanerophyte & Sudano-Zambezian \\
\hline 28. & Tribulus macropterus & Annual & Therophyte & Irano-Turanian + Mediterranean \\
\hline 29. & Trichodesma africanum & Annual & Therophyte & Saharo-Arabian + Sudano-Zambezian \\
\hline 30. & Zilla spinosa & Perennial & Chamaephyte & $\begin{array}{l}\text { Mediterranean + Saharo-Arabian+ Irano- } \\
\text { Turanian + Europian }\end{array}$ \\
\hline 31. & Ziziphus spina-christi & Perennial & Phanerophyte & Saharo-Arabian + Sudano-Zambezian \\
\hline 32. & Zygophyllum coccineum & Annual & Chamaephyte & Saharo-Arabian \\
\hline 33. & Zygophyllum simplex & Annual & Chamaephyte & Saharo-Arabian \\
\hline
\end{tabular}

The plant taxa of the study area were varied between perennial (17 species, 52\%) and annuals (48\%), the occurrence of which might has been favoured by the relatively higher water content in the valley than that of the surrounding areas. Life form spectrum of the studied species showed a wide diversity and reflects the ideal desert vegetation (Table 2 and Fig. 1C). Data on the habit and life form revealed that chamaephytic and therophytic taxa had the largest share to the total flora of the present area. Chamaephytes were composed of 14 species (43\%), followed by Phanerophytes of 10 species $(30 \%)$, Therophytes of seven species $(21 \%)$, and Hemicrytophytes of two species $(6 \%)$. The high percentage of chamaephytes and therophytes confirmed their adaptation to the dryness and deficiency of rainfall in most of the studied area. 
The taxonomic enumeration of the species per family according to this study is similar to that of the previous surveys in different regions of the Kingdom (Alatar et al., 2012; Alsherif et al., 2013; Mosallam, 2007). The record of the occurrence of Leguminosae with highest number of species, followed by Zygophyllaceae, in the study area, coincides with the finding of El-Ghanim et al. (2010) on Hail region flora. Poaceae, Leguminosae, Asteraceae represent the biggest share of plant species in Kingdom of Saudi Arabia (Al-Nafie, 2008). Similar findings were reported by different studies on the Egyptian flora (El-Ghani and El-Sawaf, 2004; El-Ghani and AbdelKhalik, 2006). The ratio of species per genus (1.06) found in this investigation is less than that that (2.6) reported for the flora of Saudi Arabia (Al-Nafie, 2008).

According to the classification of Raunkiaer (1934), chamaephytic species had the superior position, phanerophytic, therophytic and hemicryptophytic species came in the second, third and forth positions respectively. The percentage of chamaephytes, therophytes and hemicryptophytes represent about $70 \%$ of the life form spectrum within the studied area, confirming the fact that the ascendancy of Chamaephytes and Therophytes is due to the hot and dry climatic conditions in addition to the human-animals interference. This agrees with the vegetation spectra in desert habitats in other regions of the Kingdom of Saudi Arabia as previously reported (Alatar et al., 2012; Gomaa, 2012; Osman et al., 2014).

The phytogeographical investigation of the studied species displayed the superiority of monoregional taxa (49\%), followed by the bi-regional taxa (36\%). The pluri-regional taxa constituted only about $9 \%$ of all flora in the studied area (Table 2, Fig. 1D-F). The highest mono-regional elements were recorded in Saharo-Arabian region, which constitutes about $24 \%$, followed by Sudano-Zambezian region comprising about $15 \%$ of the total recorded species. While the highest bi-regional elements were detected by Saharo-Arabian- and Sudano-Zambezian regions, which constitutes $28 \%$ followed by Irano-Turanian- and Mediterranean regions comprising about 9\%.The results of chorological analysis of this study revealed that the Saharo-Arabian region harbours the highest percentage of the total plant taxa (about 39\%), which is followed by SudanoZambezian region housing 29\% for the total studied taxa. Moawed (2016) also found that most of the plant species in Alaqan area of Tabuk region, northwest of Saudi Arabia, belong to SaharoArabian or Sudano-Zambezian regions. Likewise, Alsherif et al. (2013) reported that SaharoArabian taxa had the highest contribution to the flora of Khulais region. Additionally, Seraj et al. (2014) recorded the ascendancy of Saharo-Arabian taxa in Al Soada region.

To the best of our knowledge the current investigation is the first floristic study in Wadi $\mathrm{Al}$ Aqiq and it has showed the importance of this region as important hotspot in term of plant species composition. Further studies are needed for more comprehensive analysis on the fluctuation of plant species composition, diversity and vegetation in the study area.

\section{Acknowledgments}

Authors deeply grateful to Hani Aljuhani, Zeyad Aljuhani and Nezar Aljuhani; senior students at Biology Department, College of Science, Taibah University for helping in sampling collection.

\section{References}

Al-Turki, T.A. 1997. A preliminary checklist of the flora of Qassim, Saudi Arabia. Feddes Repert. 108: 259280.

Al-Turki, T.A. and Al-Olayan, H.A. 2003. Contribution to the flora of Saudi Arabia: Hail region. Saudi J. Biol. Sci. 10: 190-222.

Alatar, A., El-Sheikh, M.A. and Thomas, J. 2012. Vegetation analysis of Wadi Al-Jufair, a hyper-arid region in Najd, Saudi Arabia. Saudi J. Biol. Sci. 19: 357-368. https://doi.org/10.1016/j.sjbs.2012.04.003 
Al-Nafie, A.H. 2008. Phytogeography of Saudi Arabia. Saudi J. Biol. Sci. 15: 159-176.

Alsherif, E.A., Ayesh, A.M. and Rawi, S.M. 2013. Floristic composition, life form and chorology of plant life at khulais region, western Saudi Arabia. Pakistan J. Bot. 45: 29-38.

Chaudhary, S.A. 2001. Flora of the Kingdom of Saudi Arabia. Ministry of Agriculture and Water. Riyadh 2 : 342-354.

Chaudhary, S.A. and Al-Jowaid, A.A.A. 1999. Vegetation of the kingdom of Saudi Arabia, Riyadh: Ministry of Agriculture and Water Press, Kingdom of Saudi Arabia.

Collenette, S. 1999. Wildflowers of Saudi Arabia. National Commission for Wildlife Conservation and Development (NCWCD), Kingdom of Saudi Arabia.

El-Ghani, M.M.A. and El-Sawaf, N. 2004. Diversity and distribution of plant species in agro-ecosystems of Egypt. Syst. Geogr. Plants 74(2): 319-336.

El-Ghani, M.M.A.B.D. andAbdel-Khalik, K.N. 2006. Floristic diversity and phytogeography of the Gebel Elba National Park, south-east Egypt. Turk. J. Bot. 30: 121-136.

El-Ghanim, W.M., Hassan, L.M., Galal, T.M. and Badr, A. 2010. Floristic composition and vegetation analysis in Hail region north of central Saudi Arabia. Saudi J. Biol. Sci. 17: 119-128. https://doi.org/ 10.1016/j.sjbs.2010.02.004

El Maghraby, M., Masoud, M. and Niyazi, B. 2014. Assessment of surface runoff in arid, data scarce regions; an approach applied in Wadi Al Hamd, Al Madinal al Munawarah, Saudi Arabia. Life Science Journal 11(4): 271-289.

Gomaa, N.H. 2012. Composition and diversity of weed communities in Al-Jouf province, northern Saudi Arabia. Saudi J. Biol. Sci. 19: 369-376.

Hosni, H.A., Hegazy, A.K. 1996. Contribution to the flora of Asir, Saudi Arabia. Candollea 51: 169-202.

Kassas, M. and Girgis, W.A. 1964. Habitat and Plant Communities in the Egyptian Desert: V. The Limestone Plateau. J. Ecol. 52: 107-119.

Llewellyn, O.A., Hall, M., Miller, A.G., Al-Abbasi, T.M., Al-Wetaid, A.H., Al-Harbi, R.J., Al-Shammari, K.F. and Al-Farhan, A. 2010. Important Plant Areas in the Arabian Peninsula: 1. Jabal Qaraqir. Edinburgh J. Bot. 67: 37-56.

Migahid, A.M. 1996. Flora of Saudi Arabia, Jeddah: King Abdul Aziz University Press. Kingdom of Saudi Arabia.

Moawed, M.M. 2016. Plant flora of Alaqan region, Tabuk province, Saudi Arabia, Egypt. J. Exp. Biol. 12: 107-113.

Mosallam, H.A.M. 2007. Comparative study on the vegetation of protected and non-protected areas, Sudera, Taif, Saudi Arabia. Int. J. Agric. Biol. 9: 202-214.

Osman, A.K., Al-Ghamdi, F. and Bawadekji, A. 2014. Floristic diversity and vegetation analysis of Wadi Arar: A typical desert Wadi of the Northern Border region of Saudi Arabia. Saudi J. Biol. Sci. 21: 554565. https://doi.org/10.1016/j.sjbs.2014.02.001

Raunkiaer, C. 1934. The life forms of plants and statistical plant geography; being the collected papers of C. Raunkiaer. life forms plants Stat. plant Geogr. being Collect. Pap. C. Raunkiaer.

Seraj, S.S., Jrais, R.N., Ayyad, S.K. 2014. Floristic composition, life form and chorology of plant life at AlSaoda, Asir Region, South-Western Saudi Arabia. J. Biol. Agric. Healthc. 4: 60-65.

Shehata, H.S. and Galal, T.M. 2015. Factors affecting the distribution and associated species of $M$ alva parviflora in the N ile D elta, E gypt. Weed Biol. Manag. 15: 42-52.

White, F. and Léonard, J. 1991. Phytogeographical links between Africa and southwest Asia. Flora Veg. Mundi 9: 229-246.

Zahran, M. 1982. Vegetation types of Saudi Arabia. King Abdel Aziz Univ. Press. Jeddah, Saudi Arab.

Zohary, M. 1973. Geobotanical foundations of the Middle East. Stuttgart: Gustav Fischer Verlag.

(Manuscript received on 14 January, 2020; revised on 23 November, 2020) 